\title{
EKSTRAK ETANOL UBI JALAR UNGU (IPOMOEA BATATAS L.) MENURUNKAN DEGENERASI LEMAK JARINGAN HATI TIKUS YANG DI OVARIEKTOMI
}

\author{
Ni Putu Candra Paramita ${ }^{1}$, I Wayan Sugiritama ${ }^{2}$, Ni Made Linawati ${ }^{2}$, IGA Dewi \\ Ratnayanti $^{2}$, Ida Ayu Ika Wahyuniari ${ }^{2}$, IGK Nyoman Arijana ${ }^{2}$, IGN Sri Wiryawan ${ }^{2}$ \\ ${ }^{1}$ Program Studi Pendidikan Dokter, Fakultas Kedokteran, Universitas Udayana \\ ${ }^{2}$ Bagian Histologi, Fakultas Kedokteran, Universitas Udayana \\ E-mail: paramitacandra@gmail.com
}

ABSTRAK

Menopause didefinisikan sebagai 1 tahun tanpa menstruasi. Wanita menopause kemungkinan berisiko mengalami Nonalcoholic Fatty Liver Disease(NAFLD). Efek menguntungkan dari antosianin telah dibuktikan dalam penelitian hewan,sehubungan dengan stres oksidatif dan steatosis hati. Ubi jalar ungu mengandung antosianin yang berfungsi sebagai antioksidan. Penelitian ini dilakukan dengan menggunakan sampel tikus yang sudah di ovariektomi, kemudian diberikan ekstrak etanol ubi jalar ungu pada tikus secara oral selama 30 hari. Pada hari pertama dilakukan randomisasi dibagi menjadi empat kelompok yaitu kelompok kontrol negatif (P0), kelompok perlakuan pemberian ekstrak etanol ubi jalar ungu dosis 1ml (P1), dosis $2 \mathrm{ml}(\mathrm{P} 2)$, dan dosis $4 \mathrm{ml}$ (P3). Pada hari ke-31 dilakukan terminasi untuk di ambil jaringan hati dan pembuatan preparat histologi, kemudian dilakukan pengamatan pada preparat dengan pembesaran 10x10 pada 2 lapang pandang. Dari 28 sampel hati tikus yang diperiksa, didapatkan semua sel hati tikus mengalami degenerasi lemak atau steatosis sebanyak $>5 \%$ yang merupakan kunci dari penyakit hati berlemak nonalkohol (NAFLD), namun jumlahnya berbeda-beda. Rerata perlemakan kelompok kontrol negatif didapatkan hasil perlemakan paling tinggi yaitu 49,1\%, kelompok perlakuan pemberian dosis $1 \mathrm{ml}, 2 \mathrm{ml}$, dan $4 \mathrm{ml}$ didapatkan hasil 39,48\%, 31,62\%, dan $29,14 \%$. Setelah diuji secara statistik didapatkan perbedaan yang signifikan $(\mathrm{p}<0,05)$ terhadap pengaruh pemberian ekstrak etanol ubi jalar ungu.Berdasarkan hasil penelitian yang telah dilakukan, maka dapat disimpulkan bahwa pemberianekstrak etanol ubi jalar ungu selama 30 hari dapat menurunkan degenerasi lemak pada hati tikus yang mengalami penyakit hati berlemak nonalkohol (NAFLD).

Kata Kunci: Ekstrak etanol ubi jalar ungu, menopause, fatty liver

\section{ABSTRACT}

Menopause is defined as 1 year without menstruation. Menopausal women areat risk of developing Nonalcoholic Fatty Liver Disease (NAFLD). The beneficial effects of anthocyanins have been demonstrated in animal studies, with respect to oxidative stress and hepatic steatosis. The purple sweet potato contains anthocyanins that act as antioxidants. This study was conducted using sample of mice that had been in ovariectomy, then given purple sweet potato ethanol extract on mice orally for 30 days. On the first day, randomization was divided into four groups; negative control group (P0), group of ethanol extract of purple sweet potato $1 \mathrm{ml}$ dose (P1), 2ml dose (P2), and $4 \mathrm{ml}$ dose $(\mathrm{P} 3)$. On the $31^{\text {st }}$ day a termination is taken to capture the liver tissue and making histology preparations, then observations are made on the preparations with 10x10 magnification in the 2 field of view. Of the 28 samples of rat liver examined, all mouse liver cells were fat or steatosis $>5 \%$, which is key to nonalcoholic fatty liver disease (NAFLD), but the numbers varies. The mean of fatty of negative control group was obtained by the highest fatty result that was $49.1 \%$, the treatment group of dose $1 \mathrm{ml}, 2 \mathrm{ml}$ and $4 \mathrm{ml}$ obtained result $39.48 \%, 31.62 \%$, and $29.14 \%$, respectively. There was significant difference $(\mathrm{p}<0.05)$ to the effect of purple sweet potato ethanol extract. Based on the results of research that has been done, it can be concluded that the ethanol extract of purple sweet potato for 30 days can decrease fat degeneration in rat liver with nonalcoholic fatty liver disease (NAFLD).

Keywords: Ethanol extract of purple sweet potato, menopause, fatty liver 


\section{PENDAHULUAN}

Menopause didefinisikan sebagai 1 tahun tanpa menstruasi.Beberapa data menyatakan bahwawanita menopause kemungkinan berisiko mengalami Nonalcoholic Fatty Liver Disease(NAFLD). ${ }^{1}$ Penurunan estrogen telah terbukti meningkatkan proses stres oksidatif dalam tubuh.Semakin tua usia tubuh, kadar antioksidan mengalami penurunan, yang rentan terhadap berbagai patologi yang berkaitan dengan usia. Penurunan ini dikombinasikan dengan hilangnya estrogen secara bertahap dalam sistem reproduksi wanita yang sangat terkait dengan berbagai gejala dari menopause. ${ }^{2}$

Menopause ditandai dengan status hormonal berubah dan dengan penurunan kualitas hidup akibat munculnya gejala tidak nyaman.Mengingat bebangejala terkait menopause, kombinasi estrogendengan progesteron sintetik telah digunakan sebagai Hormon Replacement Therapy (HRT), tersedia dan dikelola sejak1940. ${ }^{3}$

Sebuah studi telah membahas hubungan antara HRT dan NAFLD pada wanita menopause.Women Health Initiative(WHI) membuktikan bahwa HRT berbasis estrogenmemiliki efek negatif pada wanita pascamenopause, termasukpeningkatan yang signifikan dalam kejadian kanker payudara, penyakit jantung,emboli paru dan demensia vaskular dalam kelompok postmenopausewanita berusia di atas 65 tahun.Fitoestrogen merupakan bahan kimia tanaman dapat menjadialternatif untuk terapi estrogen/progesteron dan struktur kimianya mirip dengan E2/estradiol.Penggunaan fitoestrogen berasal dari studi epidemiologiyang membuktikan penurunan risiko kanker payudara, insidengejala menopause dan osteoporosis lebih rendah pada wanita dari negara-negaradengan konsumsi fitoestrogen yang tinggi. ${ }^{4}$

Flavonoid merupakan sekelompok senyawa alami yang terkenal memiliki efek estrogenik yaitu sebagai fitoestrogen. Flavonoid berfungsi sebagai salah satu target potensial untuk pengembangan suplemen alami dan obat terapi terhadap beberapa penyakit.Flavonoid merupakan sekelompok fitokimia, merujuk pada kelas tanaman metabolit sekunder.Flavonoiddapat dibagi menjadi subkelas yang berbeda, termasuk: flavon,isoflavon, flavanon, flavonol, flavanonols, chalcones, dihydrochalcones,

flavanes, antosianin, dan aurones. ${ }^{5}$

Dalam penyelidikan crosssectionalperempuan dewasa di Inggris, asupan antosianin lebih tinggidikaitkan dengan perbaikan resistensi insulin danstatus inflamasi.Ubi jalar merupakan satu dari sekian makanan yang murah yang terdapat di pasar-pasar tradisional. ${ }^{6}$ Ubi jalar memiliki zat gizi mikro yang penting yang berperan sebagai antioksidan. ${ }^{7}$

Ovariektomi pada tikus telah umum digunakan sebagai model eksperimental untuk mengetahui konsekuensi dari defisiensi estrogen. Studi membuktikan bahwa tikus yang di ovariektomi menunjukkan beberapa gejala dari sindrom metabolik, seperti peningkatan berat badan, adipositas terkait dengan akumulasi lipid hati (steatosis) dan stres oksidatif. ${ }^{8}$

Berdasarkan studi-studi tersebut, dapat diketahui bahwa menopause memiliki faktor risiko mengalami penyakit hati berlemak nonalkohol (Nonalcoholic Fatty Liver Disease/NAFLD), dan diketahui juga bahwa antosianin dapat mengobati NAFLD melalui perannya sebagai antioksidan dan fitoestrogen.

\section{BAHAN DAN METODE}

Penelitian eksperimental ini menggunakan rancangan post-test only control group. Besar sampel ditentukan dengan rumus Frederer. Berdasarkan rumus tersebut didapatkan jumlah sampel adalah 24 tikus betina dengan berat 180-220 gram yang telah diberi tindakan ovariektomi. Pemberian ekstrak etanol ubi jalar ungu pada tikus diberikan secara oral dengan menggunakan spuite. Pengelompokkan dosis pemberian ekstrak etanol ubi jalar ungu dilakukan dengan randomisasi menjadi 4 kelompok yaitu P0 yang merupakan pemberian normal saline 1 $\mathrm{ml} /$ hari, P1 yang merupakan pemberian ekstrak etanol ubi jalar ungu $1 \mathrm{ml} / \mathrm{hari}, \mathrm{P} 2$ yang merupakan pemberian ekstrak etanol ubi jalar ungu $2 \mathrm{ml} /$ hari dan P3 yang merupakan pemberian ekstrak ubi jalar ungu $4 \mathrm{ml} /$ hari. Pemberian ekstrak etanol ubi jalar ungu dilakukan selama 30 hari.

Pengambilan sampel jaringan hati berukuran sekitar $1 \mathrm{~cm}^{3}$ untuk dibuat preparat histologi dengan pewarnaan Hematoksilin dan Eosin (H\&E). Morfologi jaringan hati diamati dibawah mikroskop olympus kamera OPTILAB dengan pembesaran $100 \mathrm{x}$ pada 2 lapangan pandang.

Interpretasi sel hepatosit dilakukan berdasarkan parameter skoring histopatologi. Adanya lebih dari 5\% steatosis hepatosit pada jaringan hati merupakan kriteria minimum untuk diagnosis histologis dari NAFLD. Penilaian preparat dilakukan dengan cara menghitung jumlah inti sel yang terkena dampak dari steatosis, lalu dibagi dengan jumlah total inti sel yang ada, kemudian hasilnya dijadikan persentase. Persentase skoring yang digunakan yaitu ringan jika 0\%-33\%, sedang jika 33\%-66\% dan berat jika $>66 \%$. ${ }^{9}$ Data yang diperoleh dianalisis dengan melakukan analisis analitik, kemudian dilanjutkan dengan uji normalitas dan homogenitas serta uji One Way Anova untuk menilai efek perlakuan. 
Proses analisis dilakukan dengan menggunakan software SPSS 13.0.

HASIL

Parameter pengamatan histologi hati yang dilihat adalah perlemakan sel hati (steatosis).

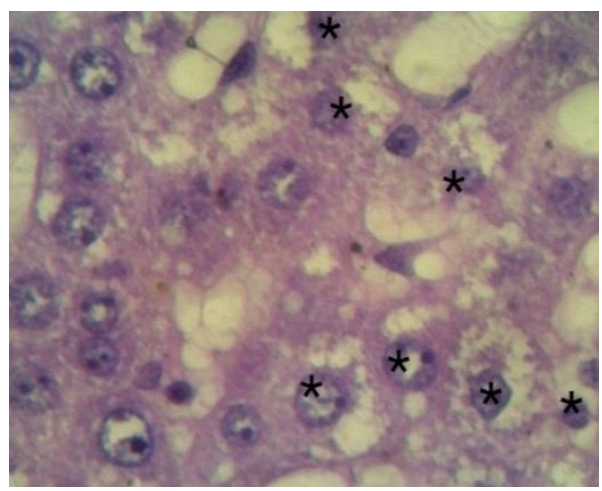

$$
\text { P1 }
$$

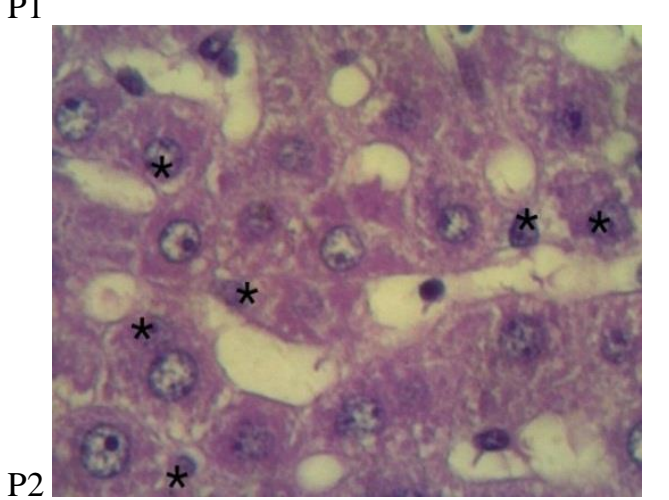

P2

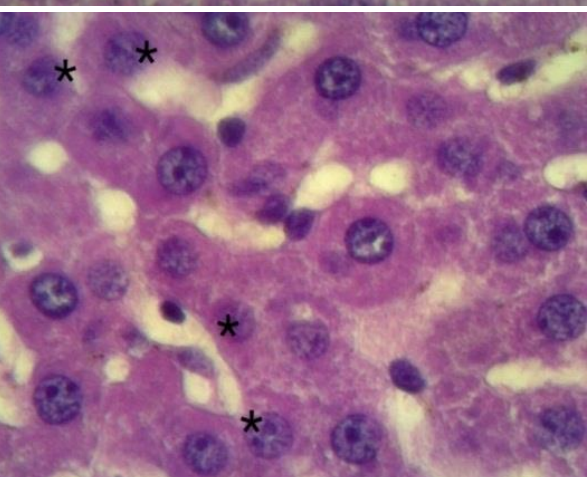

P3

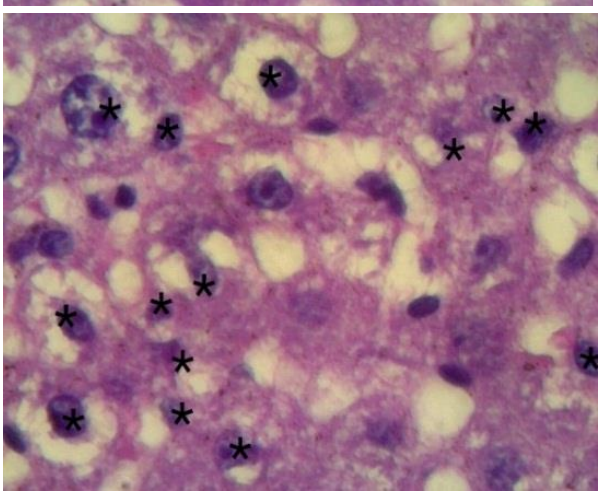

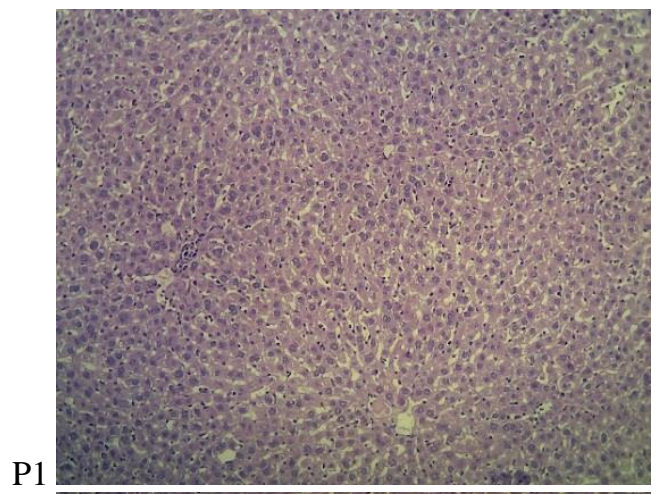

P1

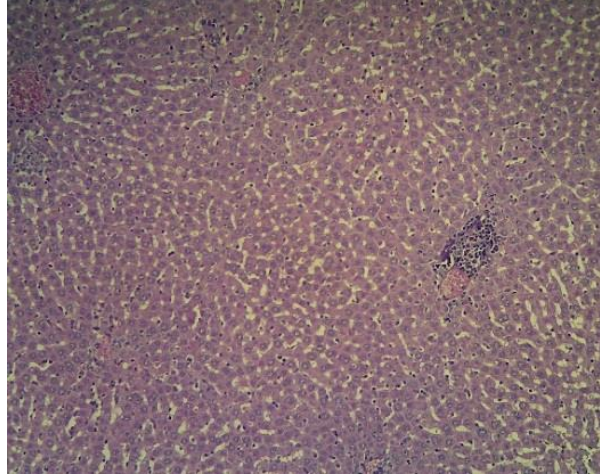

P2

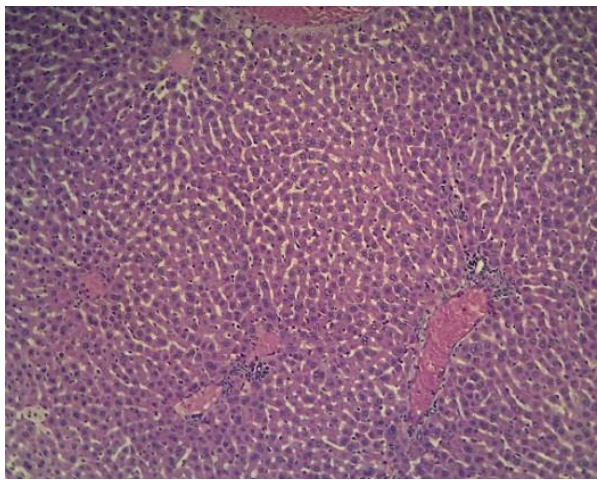

$\mathrm{P} 0$

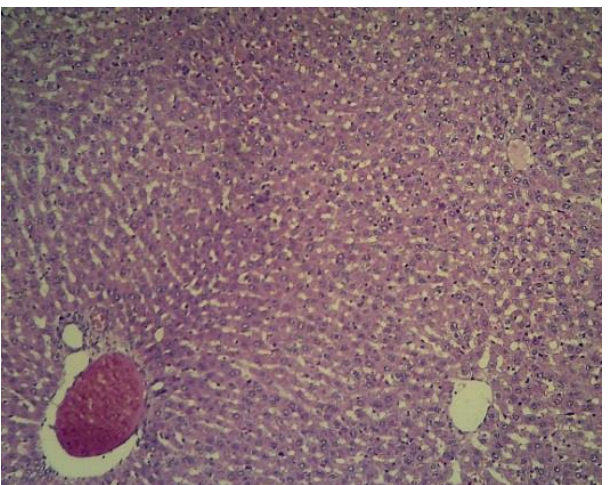

Gambar 1. Pengamatan Mikroskopis Histologi Preparat Hati Hewan Percobaan (Pembesaran 100x dan 10x).

Keterangan: $*=$ sel yang mengalami steatosis. $\mathrm{P} 0$ $=$ pemberian plasebo, $\mathrm{P} 1=$ pemberian ekstrak 1 $\mathrm{ml}, \mathrm{P} 2=$ pemberian ekstrak $2 \mathrm{ml}$, dan $\mathrm{P} 3=$ pemberian ekstrak $4 \mathrm{ml}$. 
Sel steatosis adalah sel yang mengalami perlemakan dengan ditandai oleh inti sel yang terdorong ke pinggir atau lepas dari sel parenkim hati karena adanya lemak. Setelah sel steatosis dihitung selanjutnya dilakukan analisa deskriptif, uji normalitas, uji homogenitas, dan uji komparabilitas.

Berdasarkan hasil analisis deskriptif didapatkan rerata perlemakan pada masingmasing kelompok (Tabel 1). Pemberian ekstrak etanol ubi jalar ungu pada tikus menunjukan perlemakan yang lebih rendah dibandingkan pemberian plasebo. Dari analisis ini dapat dinilai perlemakan sel hati masing-masing kelompok. Berdasarkan NAFLD/NAS skoring, perlemakan pada kelompok P0 dan P1 termasuk kategori sedang, sedangkan kelompok P2 dan P3 termasuk kategori ringan.

Tabel 1.Penilaian Perlemakan Sel Hati Hewan Percobaan

\begin{tabular}{cc}
\hline Kelompok & $\begin{array}{c}\text { Rerata } \\
\text { Perlemakan }\end{array}$ \\
\hline P0 (Plasebo) & 52,27 \\
P1 (Dosis 1 ml) & 41,74 \\
P2 (Dosis 2 ml) & 30,14 \\
P3 (Dosis 4 ml) & 27,94 \\
\hline
\end{tabular}

Data perlemakan sel hati masing-masing kelompok diuji nirmalitasnya dengan uji ShapiroWilk. Hasilnya menunjukkan bahwa data kelompok pemberian plasebo dan pemberian ekstrak etanol ubi jalar ungu berdistribusi normal (p>0,05) (Tabel 2).

Tabel 2. Hasil Uji Normalitas

\begin{tabular}{ccc}
\hline Kelompok & $\begin{array}{c}\text { Jumlah } \\
\text { Sampel }\end{array}$ & Signifikansi \\
\hline P0 & 6 & 0,508 \\
P1 & 6 & 0,792 \\
P2 & 6 & 0,416 \\
P3 & 6 & 0,570
\end{tabular}

Laveme's test dilakukan untuk mengetahui homogenitas data perlemakan sel hati masing-masing kelompok. Hasil menunjukkan bahwa data kelompok pemberian plasebo dan pemberian ekstrak ubi jalar ungu adalah homogen ( $p>0,05)$ yaitu $p=0,071$. Setelah itu hasil penelitian perlemakan sel hati hewan percobaan dianalisis dengan menggunakan one way ANOVA dengan nilai signifikansi $\mathrm{p}<0,05$. Hasilnya menunjukkan bahwa data antar kelompok terdapat perbedaan bermakna yaitu $\mathrm{p}=0,002$.
Analisis statistik dilanjutkan menggunakan uji Least Significant Difference (LSD). Dari hasil LSD, diketahui bahwa data berbeda secara nyata $(\mathrm{p}<0,05)$ antara kelompok pemberian ekstrak etanol ubi jalar ungu $1 \mathrm{ml}$ dengan kelompok $4 \mathrm{ml}$, kelompok $2 \mathrm{ml}$ dengan kelompok plasebo dan antara kelompok $4 \mathrm{ml}$ dengan kelompok plasebo (Tabel 3).

Tabel 3. Hasil Uji Komparabilitas

\begin{tabular}{ccc}
\hline \multicolumn{2}{c}{ Kelompok } & Signifikansi \\
\hline \multirow{4}{*}{ P0 } & P1 & 0,100 \\
& P2 & 0,002 \\
& P3 & 0,001 \\
P1 & P2 & 0,072 \\
& P3 & 0,035 \\
& P0 & 0,100 \\
P2 & P1 & 0,072 \\
& P3 & 0,722 \\
& P1 & 0,002 \\
P3 & P1 & 0,035 \\
& P2 & 0,722 \\
& P0 & 0,001 \\
\hline
\end{tabular}

Gambaran histologi hati masing-masing kelompok dapat dilihat pada Gambar 1. Gambaran sel hati P0 yang merupakan hasil pemberian plasebo memperlihatkan beberapa inti sel yang berada ditepi, sampai hampir lepas dari sel parenkim hati. Inti sel pada sel steatosis berada di tepi karena terdesak oleh adanya lemak yang memenuhi bagian sitoplasma sel. Pada gambar juga didapatkan sinusoid yang melebar dan terdapat sel steatosis. Sel parenkim hati terlihat memudar disertai dengan vakuola yang menunjukkan adanya perlemakan sel.

Gambaran sel hati P1 yang merupakan pemberian ekstrak etanol ubi jalar ungu dosis 1 $\mathrm{ml} /$ hari tidak terlalu memperlihatkan perbaikan. Inti sel pada sel steatosis masih banyak yang berada ditepi karena terdesak oleh adanya lemak yang memenuhi bagian sitoplasma sel, bahkan ada yang masih hampir lepas dari sel parenkim hati. Pada gambar masih terlihat sinusoid yang tidak beraturan serta tampak melebar. Sel parenkim hati terlihat memudar disertai vakuola yang menunjukkan adanya perlemakan sel.

Gambaran sel hati P2 terlihat sudah mulai mengalami perbaikan ditandai dengan sinusoid yang mulai beraturan dan lebih mendekati sel hepatosit normal. Sel steatosis masih terlihat pada gambar tersebut, namun batas sel parenkim sudah mengalami sedikit perbaikan menjadi lebih tegas dan sudah mulai terlihat sel hepatosit normal.

Gambaran sel hati P3 menunjukkan sinusoid sudah mendekati sel hepatosit normal. Batas sel parenkim hati terlihat tegas dan jelas, serta vakuola terlihat sedikit jika dibandingkan dengan P0, P1 dan P2. Inti sel pada sel steatosis terlihat lebih normal. 
Berdasarkan hasil pengamatan gambaran histologi hati terdapat beberapa tanda perlemakan hati seperti sinusoid melebar dan tidak beraturan dan sel steatosis. Perlemakan tersebut terjadi akibat ovariektomi yang dilakukan pada tikus diawal penelitian yang berpengaruh selama 30 hari penelitian.

\section{DISKUSI}

Berdasarkan NAFLD/NAS skoring, perlemakan yang terjadi pada kelompok pemberian plasebo dan kelompok perlakuan dosis $1 \mathrm{ml}$ yang hasilnya sudah dirata-ratakan termasuk kategori sedang yaitu 33\%-66\%, sedangkan pada kelompok perlakuan dosis $2 \mathrm{ml}$ dan $4 \mathrm{ml}$ yang hasilnya sudah dirata-ratakan termasuk kategori ringan yaitu 0\%-33\%. Hasil tersebut menunjukkan bahwa rerata perlemakan (steatosis) pada hati tikus baik pada kelompok perlakuan dosis $2 \mathrm{ml}$ dan $4 \mathrm{ml}$ lebih rendah dibandingkan dengan kelompok $1 \mathrm{ml}$ dan kontrol/plasebo.

Menopause dikaitkan dengan peningkatan adipositas dan risiko besar penyakit metabolik seperti peningkatan trigliserida dan kolesterol. Peningkatan trigliserida dikarenakan oleh tingginya asam lemak bebas dalam hati yang diakibatkan oleh lipogenesis yang meningkat juga. Peningkatan trigliserida ini kemudian menyebabkan tingginya VLDL maka terjadilah akumulasi lemak dalam hati. ${ }^{10}$

Pada wanita menopause, jumlah estrogen menurun. ${ }^{11}$ Estrogen dikaitkan dengan penurunan ekspresi gen yang terlibat dalam lipogenesis termasuk asetil-koenzim A (CoA), carboxylate- $\alpha$ dan $-\beta$, dan elemen pengikat regulasi sterol $1 \mathrm{c}$ (SREBP-1c). E2/estradiol menekan gen lipogenik dan akumulasi trigliserida di hati. ${ }^{12}$ Jika estrogen menurun pada wanita maka peran estrogen pun menurun sehingga terjadilah gangguan profil lipid yaitu meningkatkan lipogenesis. Lipogenesis yang meningkat menyebabkan pembentukan asam lemak bebas yang meningkat juga di hepar yang berakhir pada akumulasi lemak. Selain itu, akan terjadi berkurangnya kecepatan transport lemak hepar yang disebabkan menurunnya sintesis dan ekspresi apolipoprotein $\mathrm{B}$ oleh penurunan estrogen, sehingga cadangan lemak menumpuk dalam hepar. ${ }^{13}$ Pada wanita postmenopause juga mengalami lipolisis basal yang menurun, sehingga akan menyebabkan akumulasi lemak pada hati dikarenakan terhambatnya pelepasan asam lemak bebas ke dalam aliran darah untuk diedarkan ke seluruh tubuh. ${ }^{14}$

Stres oksidatif juga berperan dalam mekanisme NAFLD ini. Dimana jalur kompensasi akibat penumpukan lemak yang berlebihan di hepar adalah aktivasi beta oksidasi asam lemak mitokondria karena desentisasi dari carnitine palmitoyltransferase (CPT-I) yang merupakan gerbang yang mengatur masuknya asam lemak rantai panjang ke dalam mitokondria. Hal inilah yang mendasari kompleks-kompleks yang tereduksi akan bereaksi dengan oksigen untuk membentuk reactive oxygen species (ROS). ROS mengoksidasi asam lemak tidak jenuh yang menyebabkan lipid peroksidasi membentuk produk-produk seperti 4-hydroxynonenal (HNE) dan malondialdehyde (MDA). ROS dan produkproduk reaktif aldehid lipid peroksidasi secara langsung merusak DNA mitokondria. Selanjutnya, produksi ROS yang berlebihan meningkatkan ekspresi beberapa sitokin-sitokin (TNF- $\alpha$, TGF beta, fas ligad, IL-8).dalam sel hepar. Bahan-bahan antioksidan tidak mencukupi untuk menetralkan peningkatan kadar ROS sehingga mengakibatkan nekroinflamasi. ROS menyebabkan apoptosis sel secara langsung melalui aktivasi NF-kB. ${ }^{13,15}$

Pada kelompok plasebo, pemberian ekstrak etanol ubi jalar ungu $1 \mathrm{ml}$, dan $2 \mathrm{ml}$ didapatkan sinusoid yang tidak beraturan sampai dengan melebar, ini dikarenakan degenerasi lemak sel hati dapat menyebabkan terjadinya perubahan susunan sel sehingga sel tidak mampu kembali kekeadaan semula dan menyebabkan sinusoid yang melebar. ${ }^{16}$ Tidak beraturnya letak sinusoid kemungkinan juga disebabkan oleh terjadinya peroksidasi lipid dan stres oksidatif yang kemudian meningkatkan produksi hidroksineonal (HNE) dan malondialdehid (MDA) yang meningkatkan fibrosis hati melalui aktivasi oleh sel stelata yang menyebabkan peningkatan produksi transforming growth factor-beta (TGFß). ${ }^{17}$

Ubi jalar ungu memiliki kandungan antosianin yang berperan sebagai fitoestrogen pada wanita menopause. Antosianin yang terdapat pada ekstrak ubi jalar ungu menurunkan akumulasi lemak dalam hati melalui dua mekanisme yaitu yang pertama menekan Srebp1c kemudian akan menekan lipogenesis, dan yang kedua yaitu meningkatkan PPAR $\alpha$ yang akan menyebabkan meningkatnya lipolisis dan keduanya akan menekan kerusakan pada hati yang disebabkan oleh NAFLD. ${ }^{18}$ Uji klinis terbaru juga telah menyelidikiefek mengkonsumsi makanan dan minuman yang kaya antosianin pada orang dengan NAFLD. Konsumsi ubi jalar ungu dikaitkan dengan efek yang menguntungkan dalam menurunkanserum g-glutamyl transferase dan tingkat SGPT(ALT) yang meningkat pada NAFLD. ${ }^{3}$ Studi lain menyatakan peran flavonoid (yang salah satu subkelasnya adalah antosianin) dapat menjadi pereduksi LDL dalam tubuh. Selain mereduksi LDL, flavonoid juga dapat meningkatkan densitas reseptor LDL dihati dan mengikat apolipoprotein B. ${ }^{19}$ 
Hasil analisis data antar kelompok satu dan lainnya ada yang bermakna dan tidak bermakna, namun secara keseluruhan terdapat perbedaan yang bermakna dan signifikan $(\mathrm{p}<0,05)$. Hasil penelitian dan analisis data dari kelompok kontrol/plasebo dengan kelompok ekstrak etanol ubi jalar ungu dosis $2 \mathrm{ml}$ dan $4 \mathrm{ml}$, kelompok dosis $4 \mathrm{ml}$ dengan kelompok dosis $1 \mathrm{ml}$, menunjukkan perbedaan yang bermakna $(\mathrm{p}<0,05)$. Sedangkan kelompok kontrol/plasebo dengan kelompok dosis $1 \mathrm{ml}$, kelompok dosis $1 \mathrm{ml}$ dan 4 $\mathrm{ml}$ dengan $2 \mathrm{ml}$, tidak menunjukkan perbedaan secara bermakna $(p>0,05)$. Hal tersebut dikarenakan pemberian ekstrak etanol ubi jalar ungu dengan dosis yang relatif lebih tinggi dapat mencegah perlemakan pada sel hati pada hewan percobaan, terutama karena kandungan antosianin, yang berfungsi sebagai antioksidan dan juga peran fitoestrogeniknya pada tikus yang diovariektomi ini.

Perbedaan hasil dari setiap perlakuan dikarenakan pemberian ekstrak etanol ubi jalar ungu dosisnya berbeda-beda. Sehingga ada perbedaan jika pada pemberian dosis lebih kecil apalagi pemberian plasebo memperlihatkan hasil yang lebih tinggi perlemakannya. Karena seperti yang dibahas sebelumnya, ubi jalar ungu mengandung antioksidan, fitoesterogen bahkan antiinflamasi yang baik untuk penurunan jumlah degenerasi lemak dari NAFLD. Ukuran sinusoid dan batas sel juga terlihat berbeda dikarenakan proses perlemakan yang terjadi dan perbedaan pemberian dosis ekstrak etanol ubi jalar ungu pada masing-masing kelompok.

Berdasarkan uraian diatas, terlihat ekstrak etanol ubi jalar ungu dengan adanya senyawa antosianin yang merupakan salah satu golongan dari flavonoid kemungkinan dapat memperbaiki kerusakan sel hati yang mengalami perlemakan. Efek antioksidan dan fitoestrogen tersebut dapat terlihat lebih banyak pada P3 (dosis $4 \mathrm{ml}$ ), tetapi perlu dilakukan penelitian lebih lanjut untuk menentukan dosis optimum yang dapat mengurangi perlemakan hati.

\section{SIMPULAN}

Berdasarkan hasil penelitian yang telah dilakukan, maka dapat disimpulkan bahwa pemberian ekstrak etanol ubi jalar ungu dapat menurunkan degenerasi lemak pada hati tikus yang mengalami penyakit hati berlemak nonalkohol (NAFLD).

\section{SARAN}

Saran yang dapat diberikan untuk penelitian selanjutnya yaitu perlu dilakukan penelitian lebih lanjut untuk mengetahui dosis optimum yang mendekati dosis $4 \mathrm{ml}$ dalam mengurangi perlemakan hati, dosis ekstrak etanol ubi jalar ungu $1 \mathrm{ml}$ belum cukup untuk mencegah perlemakan pada sel hati tikus secara bermakna, maka untuk penelitian selanjutnya perlu dilakukan peningkatan dosis pada perlakuan, durasi pemberian ekstrak etanol ubi jalar ungu tidak cukup lama untuk menghasilkan efek seperti yang diharapkan, maka mungkin dibutuhkan durasi lebih lama lagi untuk pemberian ekstrak etanol ubi jalar ungu.

\section{DAFTAR PUSTAKA}

1. Brady CW. Liver Disease in Menopause. World Journal Gastroenterology. 2015; 21(25):7613-20.

2. Doshi SB, Agarwal, A. The Role of Oxidative Stress in Menopause. Journal of Mid-Life Health. 2013; 4(3):140-6.

3. Zhang PW, Chen FX, Ling WH, Guo HH. A Consort-Compliant,Randomized, DoubleBlind, Placebo-Controlled Pilot Trial of Purified Anthocyanin in Patients With Nonalcoholic Fatty Liver Disease.Medicine (Baltimore) Journal. 2015; 94(20):e758.

4. Moreira AC, Silva AM, Correia S, Sardao VA. Phytoestrogens Asalternative Hormone Replacement Therapy in Menopause: What is Real, What is Unknown. Journal Steroid Biochemistry Molecular Biology. 2014; 143(20):61-71.

5. Roy CYC, Judy TTZ, Amanda WYY, Pinky SCL, Sherryl LX, Ava JYG, Kevin YZ, Tina TXD, Karl, WKT. Synergistic Action of Flavonoids, Baicalein, and Daidzein in Estrogenic and Neuroprotective Effects: a Development of Potential Health Products and Therapeutic Drugs Against Alzheimer's Disease. Evidence-based Complementary and Alternative Medicine. 2013; (1):635-94.

6. Yao H, Qiao YJ, Zhao YL, Tao XF, Xu LN, Yin LH, Qi Y, Peng JY. Herbal Medicines and Nonalcoholic Fatty Liver Disease. World Journal Gastroenterology. 2016; 22(30):6890-905.

7 Sabuluntika N. Kadar $\beta$-karoten, Antosianin, Isoflavon, dan Aktivitas Antioksidan Pada Snack Bar UbiJalar Kedelai Hitam Sebagai Alternatif Makanan Selingan Penderita Diabetes Melitus Tipe 2. Journal of Nutrition College.2013; 2(4):146-52.

8. HermosoDAM, Shimada LBC, Gilglioni EH, Constantin J, Mito MS, Hermoso APM, Pagadigorria CLS, Iwamoto ELI. 2016. Melatonin Protects Female Rats Against Steatosis and Liver Oxidative Stress Induced by Oestrogen Deficiency. Life Sciences. 2016; 157:178-86.

9. Brunt EM, Tiniakos DG. Histopathology of Nonalcoholic Fatty Liver Disease.World Journal Gastroenterology. 2010; 16(42):5286-96. 
10. Kneeman JM, Misdraji J, Corey KE. Secondary Causes of Nonalcoholic Fatty Liver Disease. Therapeutic Advances in Gastroenterology. 2012; 5(3):199-207.

11. Goodman NF, Cobin RH, Ginzburg SM, Katz IA, Woode DE. AACE Medical guidelines For Clinical Practice For the Diagnosis and Treatment of Menopause. American Association of Clinical Endocrinologists. 2011; 17(6):1-25.

12. Jarvis FM, Clegg DJ, Hevener AL. The Role of Estrogens in Control of

Energy Balance and Glucose Homeostasis. Endocrine Society. 2013; 34(3):309-38.

13. Diane Y, Sayoeti Y. 2014. Peran Antioksidan Pada Non Alcoholic Fatty Liver Disease (NAFLD). Andalas Journal of Health. 2014; 3(1):338-67.

14. Berman DM, Niclas BJ, Ryan AS, Rogus EM, Dennis KE, Goldberg AP. Regulation of Lipolysis and Lipoprotein Lipase After Weight Loss in Obese, Postmenopausal Women.Obesity Research. 2010; 12(1):32-9.
15. Krismayogi GA, Ratnayanti ID, Linawati NM, Wiryawan IS, Sugiritama IW, Wahyuniari IAI, Arijana IN. Purple Cabbage Extract Cream Effect on Erythema Score of Male Wistar Rats Back Skin Exposed to UVB Radiation. Biomedical and Pharmacology Journal. 2018; 11(1):343-51.

16. Wulandar D. Kadar Malondialdehida (MDA) dan Gambaran Histopatologi Organ Hati pada Hewan Model Tikus (Rattus Norvegicus) Hiperkolesterolemia Setelah Terapi Ekstrak Air Benalu Mangga. (Dendrophthoe Pentandra L. Miq)'. Fakultas Kedokteran Hewan, Universitas Brawijaya. 2012.

17. Fabregat I Sancho P. The Transforming Growth Factor-Beta (TGF- $\beta$ ) in Liver Fibrosis.Federation of European Biochemical Societies Journal. 2013; 283(12):2219-32.

18. Valenti L,Riso P, Mazzocchi A, Porrini M, Fargion S.,Agostoni C. Dietary Anthocyanins as Nutrition Therapy For Nonalcoholic Fatty Liver Disease.Oxidative Medicine and Cellular Longevity. 2013; 29(12):1-11.

19. Sulaiman CT, Arun A, Anandan EM., Sandhya CR., Balachandran. Isolation and Identification of Phytoestrogen and Flavonoids in an Ayurvedic Proprietary Medicine using Chromatographic and Mass Spectroscopic Analysis. Asian Pacific Journal of Reproduction. 2015; 4(2):153-6. 